\title{
積層ゴム系免震構造の安全裕度に関する基礎的考察
}

\author{
深沢 剛司 ${ }^{* 1}$, 宮川 高行*2, 内田 昌人*3, 山本 智彦*4 \\ 宮崎 真之*4，岡村 茂樹*5，藤田 聡 ${ }^{* 6}$
}

\section{Fundamental study on seismic safety margin for seismic isolated structure using the laminated rubber bearings}

\author{
Tsuyoshi FUKASAWA*1, Takayuki MIYAGAWA ${ }^{* 2}$, Masato UCHITA*3, Tomohiko YAMAMOTO*4, \\ Masashi MIYAZAKI*4, Shigeki OKAMURA*5 and Satoshi FUJITA*6 \\ ${ }^{* 1}$ Department of Mechanical Engineering, Tokyo Denki University ( Former Mitsubishi FBR Systems, Inc.) \\ 5 Asahi-cho, Adachi-ku, Tokyo 120-8551, Japan \\ ${ }^{*} 2,{ }^{* 3}$ Japan Atomic Power Company \\ 5-2-1 Ueno, Taitou-ku, Tokyo 110-0005, Japan \\ ${ }^{*}$ Japan Atomic Energy Agency \\ 4002 Narita-cho, O-arai-machi, Higashiibaraki-gun, Ibaraki 311-1393, Japan \\ ${ }^{* 5}$ Department of Mechanical System Engineering, Toyama Prefectural University \\ 5180 Kurokawa, Imizu-shi, Toyama 939-0398, Japan \\ ${ }^{* 6}$ Department of Mechanical Engineering, Tokyo Denki University \\ 5 Asahi-cho, Adachi-ku, Tokyo 120-8551, Japan
}

Received: 24 December 2020; Revised: 15 March 2021; Accepted: 12 May 2021

\begin{abstract}
This paper describes a fundamental study on the seismic safety margin for isolated structures using laminated rubber bearings. The variation of the seismic response assumed in the isolated structures will occur under the superposition of "Variations in seismic response due to input ground motions" and " Manufacturing error of the isolation devices". The seismic response analysis that allows for their conditions is important to assess the seismic safety margin for the isolated structures. The variation of the seismic response due to the superposition of these conditions can underestimate the seismic safety margin of the isolated structures. This paper clarifies that the seismic safety margin of the isolated structure, which consists of rubber bearings and oil dampers, for Sodium-cooled Fast Reactor (SFR) is ensured against the basis ground motions of the Japan Electric Association Guide 4601 (JEAG4601) and the SFR through the seismic response analyses. The seismic response analyses were performed by considering the superposition of the variation factors, such as the input ground motions and the manufacturing error of the isolation devices. Additionally, a relationship between the seismic safety margin and the excess probability of linearity limits was discussed using the results obtained from the seismic response analysis. The required seismic safety margins to satisfy the excess probability of linearity limits were clarified by that relationship.
\end{abstract}

Keywords : Isolated structure, Seismic safety margin, Variation of seismic response, Seismic response analysis, Rubber bearings

No.21-00007 [DOI:10.1299/transjsme.21-00007], J-STAGE Advance Publication date : 20 May, 2021

本論文は，Dynamics and Design Conference 2020 講演論文集(2020), No.235の掲載内容に基づいた論文である.

${ }^{* 1}$ 正員, 東京電機大学 工学部機械工学科（元 三菱 FBR システムズ (株)）（テ120-8551 東京都足立区千住旭町 5)

*2 正員, 日本原子力発電 (株) (厂110-0005 東京都台東区上野 5-2-1)

*3 日本原子力発電 (株)

*4 正員, (国研) 日本原子力研究開発機構（广311-1393 茨城県東茨城郡大洗町成田町 4002）

*5 正員, 富山県立大学 工学部機械システム工学科（广939-0398 富山県射水市黒河 5180)

*6 名誉員, 東京電機大学 工学部機械工学科

E-mail of corresponding author: t.fukasawa@mail.dendai.ac.jp 
Fukasawa, Miyagawa, Uchita, Yamamoto, Miyazaki, Okamura and Fujita, Transactions of the JSME (in Japanese), Vol.87, No.898 (2021)

\section{1. 緒言}

\section{$1 \cdot 1$ 背景 $\cdot$ 目的}

構造物の地震に対する構造健全性を評価する一つの方法として, 時刻歴応答解析が利用されている. 原子力施 設を対象とした場合，その入力地震動は「原子力発電所耐震設計技術指針 JEAG4601-2015」（以下，JEAG4601 と称す）にて規定されたターゲットスペクトルに適合する模擬地震動が利用される.JEAG4601 では, 減衰定数 h を 0.05 とするターゲットスペクトルに適合する模擬地震動を作成するように規定されている. しかし，免震構造 の場合，地震時の応答変位を抑制するために少なくとても 0.2 以上の減衰定数を有しており，高速炉の原子炬建 屋 (免震構造) では減衰定数が 0.4 程度となっている(深沢他, 2018). このように, 免震構造の減衰定数と JEAG4601 で規定される 0.05 の減衰定数（非免震構造）とでは大きく異なる. そのため, 免震構造の場合には JEAG4601 で 規定されているターゲットスペクトルへの適合度を満た寸模擬地震動であっても地震応答にばらつきを生じる恐 れがある.

原子力施設向けの免震構造に係る技術指針として，「原子力発電所免震構造設計技術指針（以下，JEAG4614 と 称す)」が整備されている．JEAG4614 では基準地震動に対する免震装置（積層ゴム系免震装置）の設計上の許容 限界が規定されている. その許容限界は軸応力一せん断ひずみ関係に破断曲面と線形限界曲面をプロットのうえ, 線形限界曲面と基準地震動で生じる応答との比率で定められている．著者らが破断試験を基に作成した線形限界 曲面によれば，高速炉で対象とする積層ゴム形状の線形限界曲面は，軸応力とせん断ひずみによって変化するこ とが確認されている(深沢他，2017a) (Fukasawa, et al., 2018)。これは，設計上の許容限界が地震応答によって変動 することを意味している，よって，許容限界に対する免震装置の安全余裕を評価する際には，地震応答のばらつ きと，これによって変動する許容限界を踏まえて検証することが重要となる.

加えて, 免震構造の地震応答のばらつきに影響を及ぼす因子としては複数基設置される免震装置諸元のばらつ きも挙げられる，製作される免震装置は程度の差こそあれ，設計值に対して誤差が含まれることとなり，これが 地震応答のばらつきの一つの要因につながる. 免震を対象とする構造物の質量にもよるが, プラントで導入され る免震装置の基数は数百基となることが想定され，その基数が設計值に及ぼす影響を設計段階で把握することが 重要となる.

したがって, 免震構造で想定される地震応答のばらつきは「入力地震動による地震応答のばらつき」と「免震 装置の製作に伴う設計值との誤差およびその誤差を導入基数で組み合わせた際の地震応答のばらつき」との重畳 で生じることとなる，そのため，免震構造の安全余裕は，それらの条件を重畳させた地震応答を用いて考察する ことが重要であるといえよう.

そこで，高速炉向けの免震システムを対象に，地震応答のばらつきを誘発する因子として模擬地震動の特性と 免震装置の諸元に着目して，それらを重畳させた際の地震応答のばらつきを地震応答解析によって評価する．ま た，この結果を用いて設計上の許容限界に対する安全余裕について基礎的な考察を行う.

\section{$1 \cdot 2$ 論文の構成}

本論文は以下のとおり構成されている. 第 2 章では本論文で詨象とする高速炉向けの免震システムの主要な諸 元について触れ, 第 3 章ではターゲットスペクトルが異なる模擬地震動を複数波作成して, 免震構造で想定され る固有周期領域と減衰定数領域で地震応答のばらつきを評価する．第 4 章では，免震装置の基数が設計諸元に及 ぼす影響をモンテカルロ法で評価する．第 5 章では，第 3 章と第 4 章の結果を踏まえて，模擬地震動の特性と免 震装置の諸元を考慮した地震応答解析を行う。 また，第 6 章では地震応答解析結果から，JEAG4614 に準拠して 許容限界に対する安全余裕を評価するとともに, 確率論的な観点からも考察を加える. 最後に, 第 7 章では本検 討で得られた結果を要約する.

\section{2. 高速炉向けの免震システムの主要な諸元}

本論文では厚肉積層ゴムとオイルダンパから構成される図 1 の免震システムを対象とする. それらの主な仕様 は以下となる. 
Fukasawa, Miyagawa, Uchita, Yamamoto, Miyazaki, Okamura and Fujita,

Transactions of the JSME (in Japanese), Vol.87, No.898 (2021)

厚肉積層ゴムは水平・上下方向の地震応答低減を目的として開発されたものであり，一般的な積層ゴムと比べ て, 2 倍以上のゴム層厚となっている. 直径は $1600 \mathrm{~mm}$ であり, その一次形状係数 $\mathrm{S} 1$ と二次形状係数 S2 は各々 12.26 と 5.16 である. またゴムのせん断弾性係数は $0.539 \mathrm{MPa}$ である. この形状とゴムのせん断弹性係数によっ て与えられる設計面圧 $5.0 \mathrm{MPa}$ での水平・上下方向の固有周期は各々 3.4 秒と 0.133 秒となる.

オイルダンパは，その減衰力特性として荷重一速度関係が線形特性を有するものを導入する．ここで用いるオ イルダンパは，オイルの圧力と流量を制御するための制御弁が設けられているものであり，動粘度が比較的低い $\left(20^{\circ} \mathrm{C}\right.$ で約 $20.6 \mathrm{~mm}^{2} / \mathrm{s}$ 程度）オイルが内包されている. オイルダンパの一基あたりの減衰係数を $2000 \mathrm{kN} /(\mathrm{m} / \mathrm{s})$ として，基準地震動に対して応答変位（中央值）が $0.35 \mathrm{~m}$ 以下となるように減衰力を与える. この応答変位は, 設計面圧で水平方向の許容限界（JEAG4614 で規定される設計上の許容限界）に対して，2 倍の安全余裕を確保し たものとなっている．なお，基準地震動に対する応答変位が $0.35 \mathrm{~m}$ 以下となる場合には 0.2 以上の減衰定数 $\mathrm{h}$ を 与える.

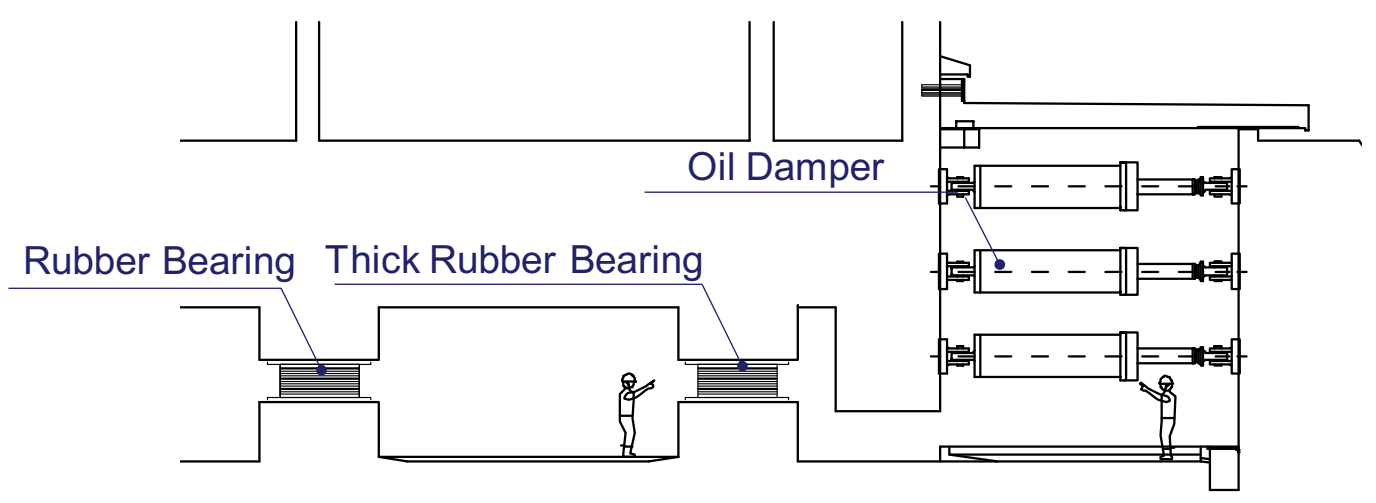

Fig. 1 Seismic isolation system for SFR consisting of thick rubber bearings and oil dampers. The thick rubber bearings, which have two times thicker than pervious rubber bearings, are applied to reduce the vertical seismic response as well as horizontal seismic response. The oil dampers are used, which have a linear damping characteristic between the force and velocity.

\section{3. 模擬地震動が地震応答に及ぼす影響}

ここでは 2 種類の基準地震動のターゲットスペクトルに適合する模擬地震動を各々 100 波作成して，免震構造 で想定される固有周期領域と減衰定数領域で地震応答のばらつきを評価する.

\section{$3 \cdot 1$ 模擬地震動の作成}

模擬地震動の作成で対象とするターゲットスペクトルは，減衰定数 $\mathrm{h}$ が 0.05 で規定された「高速炉の設計検討 で用いられている基準地震動（以下，高速炉の基準地震動と称す)」(深沢他，2017b)と JEAG4601 の「震源を特 定せず策定する地震動」とした，模擬地震動は，これらのターゲットスペクトルに適合するように各々 100 波作 成した。 ここでは，せん断波速度 $V \mathrm{~s}$ および $P$ 波速度 $V \mathrm{p}$ は各々 $1500 \mathrm{~m} / \mathrm{s}$ および $3000 \mathrm{~m} / \mathrm{s}$ と仮定した. なお，高速 炉の基準地震動（水平方向）の最大加速度と最大速度は各々 $8.0 \mathrm{~m} / \mathrm{s}^{2}$ と $2.0 \mathrm{~m} / \mathrm{s}$ である. 上下方向については，水 平方向の $2 / 3$ 倍としている.

2 種類の基準地震動を対象に作成した模擬地震動の擬似速度応答スペクトル（計 100 波）を図 2 , 図 3 に示す. 擬似速度応答スペクトルの算出に用いた減衰定数は，0.05，0.02，0.40 とした.これらの減衰定数について補足寸 る. 0.05 についてはJEAG4601 に準拠したものであり，0.02 と 0.40 については高速炉の免震システムで想定され る上下方向と水平方向の減衰定数である.

JEAG4601 で規定される減衰定数 0.05 における模擬地震動の擬似速度応答スペクトルについては, ターゲット スペクトルとの高い適合性が確認できる，一方，それ以外の減衰定数については擬似速度応答スペクトルにばら つきが認められる．この傾向はターゲットスペクトルの形状や減衰定数によらず，幅広い固有周期領域で応答の ばらつきが確認された。 
Fukasawa, Miyagawa, Uchita, Yamamoto, Miyazaki, Okamura and Fujita, Transactions of the JSME (in Japanese), Vol.87, No.898 (2021)

\section{$3 \cdot 2$ 擬似速度応答のばらつき評価}

上記で確認された擬似速度応答スペクトルのばらつきを標本データとして，信頼区間に基づき各減衰定数での 応答のばらつきを評価する. 図 4 に水平方向の固有周期を 3.4 秒 (免震の固有周期), 減衰定数 $\mathrm{h}$ を $0.05,0.40$ と して得られた擬似速度応答の確率密度関数とヒストグラムを示している，なお，確率密度関数については，各減 衰定数の確率密度関数の最大值で正規化したものとなっている. 図 4 の両減衰定数で得られた擬似速度応答の頻 度は正規分布で与えた確率密度関数とよく対応している.

次に，この確率密度関数の形状についてみていく，減衰定数が 0.05 の場合，確率密度関数には明瞭なピークが 中央值（1.0）で生じている. 一方，減衰定数が 0.40 の場合, 確率密度関数のピークは中央值に対応しているが, その形状は 0.05 のそれと比較して相対的に広がりを有するものとなっている. これは減衰定数が 0.05 から 0.40 に変化することで，擬似速度応答のばらつきが大きくなることを意味している.

加えて，免震構造で想定される固有周期領域（3 秒から 4 秒）を対象に上記と同じ方法で整理したものが図 5 となる.これらの確率密度関数は各減衰定数間で対応していることから, 固有周期の変化が擬似速度応答のばら つきに及ぼす影響は軽微であるといえる.これは水平方向だけではなく, 上下方向の模擬地震動と減衰定数 (0.02) を評価対象とした場合でも同様の傾向が確認された.

以上の結果を 95\%と 99.7\%信頼区間で評価すると以下となる．なお，これらの信頼区間の算出で対象とした水 平・上下方向の固有周期は，高速炉の免震システムの 1 次モードとして想定される各々 3.4 秒と 0.133 秒とした.

- 減衰定数 $\mathrm{h}=0.05$

- 95\%信頼区間 : $\pm 2 \% ， 99.7$ 信頼区間 : $\pm 3 \%$

- 減衰定数 $\mathrm{h}=0.02,0.4$

- 95\%信頼区間 : $\pm 20 \% ， 99.7$ 信頼区間 : $\pm 30 \%$

上記の信頼区間は，各減衰定数で得られた擬似速度応答の中央值で正規化したものとなっている．これらの信 頼区間から，JEAG4601 で規定される減衰定数（h:0.05）では擬似速度応答のばらつきは小さく，中央值を基準に 99.7\%信頼区間で土3\%程度となった。一方，高速炉の免震システムで想定される減衰定数（水平方向 h:0.40，上 下方向 h : 0.02) では，95\%信頼区間で $\pm 20 \%$ 程度，99.7\%信頼区間で $\pm 30 \%$ 程度の擬似速度応答のばらつきが確 認された.

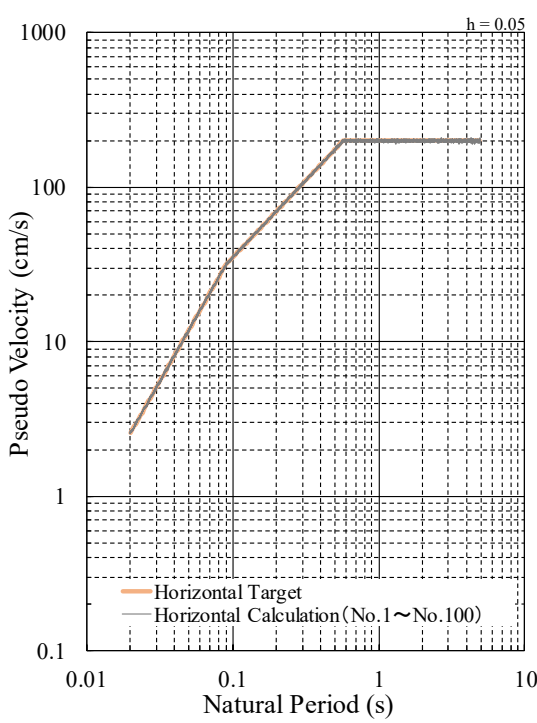

(a) $\mathrm{h}=0.05$

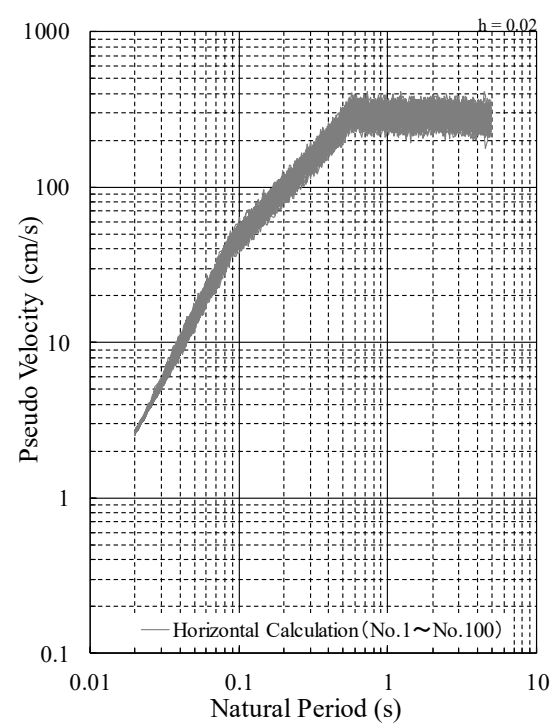

(b) $\mathrm{h}=0.02$

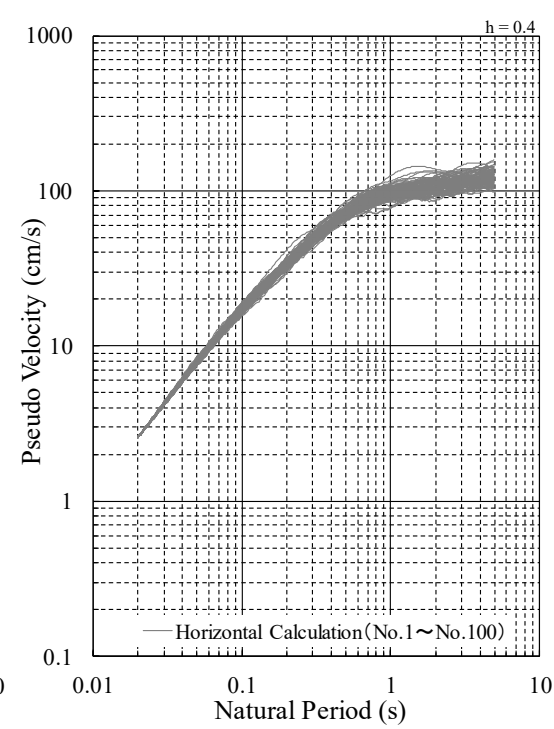

(c) $\mathrm{h}=0.40$

Fig. 2 Response spectra of simulated earthquake ground motions with target spectrum $(\mathrm{h}=0.05)$ of SFR in horizontal direction. The response spectra calculated by damping factor of 0.05 accurately accord with the target spectrum with damping factor of 0.05 . In contrast, the response spectra calculated by other damping factors have significant variation. 
Fukasawa, Miyagawa, Uchita, Yamamoto, Miyazaki, Okamura and Fujita,

Transactions of the JSME (in Japanese), Vol.87, No.898 (2021)

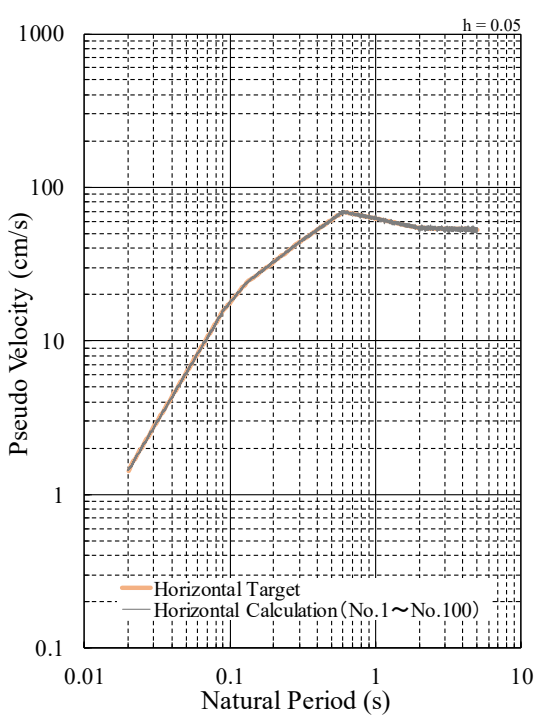

(a) $\mathrm{h}=0.05$

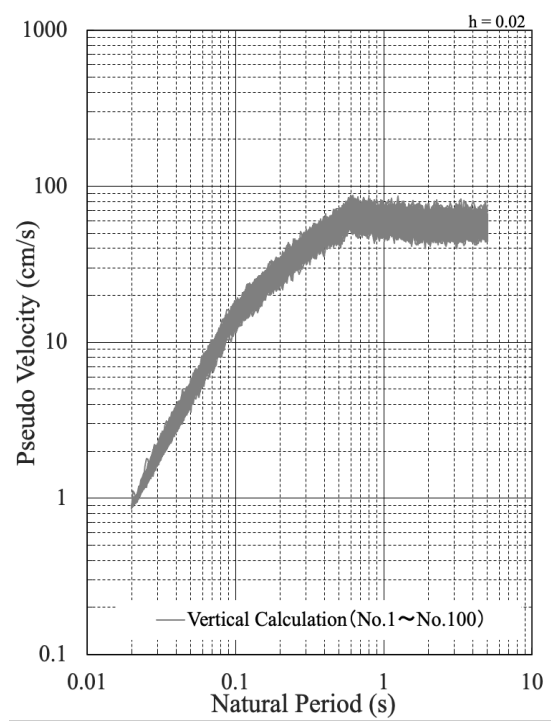

(b) $\mathrm{h}=0.02$

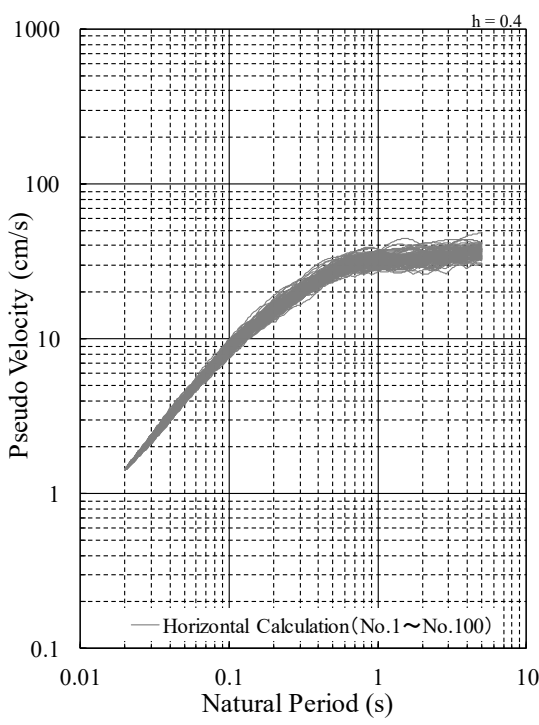

(c) $\mathrm{h}=0.40$

Fig. 3 Response spectra of simulated earthquake ground motions with target spectrum $(\mathrm{h}=0.05)$ of ground motion with non-specified source in horizontal and vertical direction. The response spectra calculated by the damping factor of 0.05 accurately accord with the target spectrum with damping factor of 0.05 . The response spectra calculated by other damping factors have significant variation.

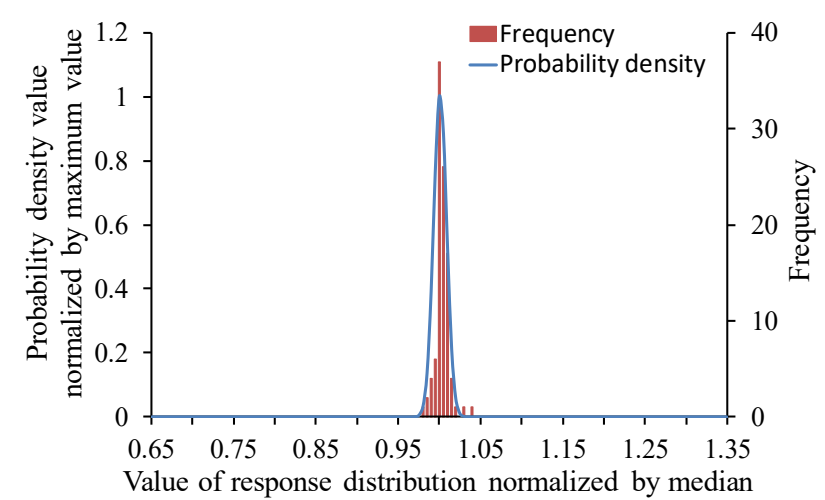

(a) $\mathrm{h}=0.05$

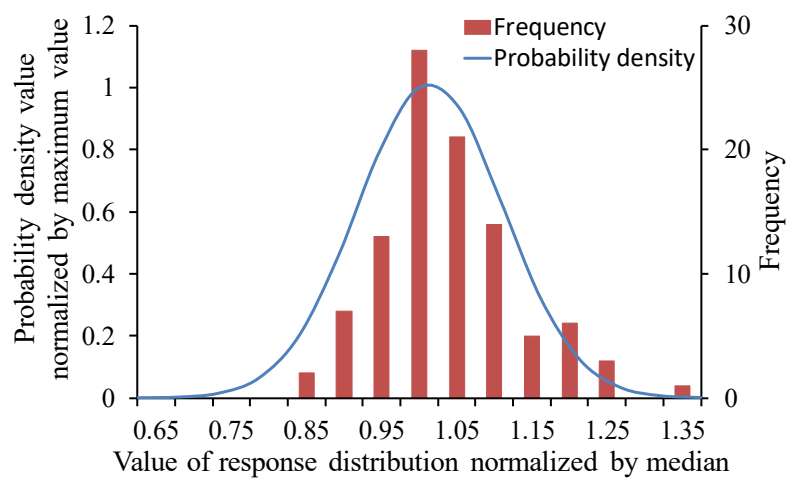

(b) $\mathrm{h}=0.40$

Fig. 4 Comparison of probability density functions with damping factors of 0.05 and 0.4 concerning horizontal natural period of $3.4 \mathrm{~s}$. The probability density function of the damping factor of 0.05 yields a small standard deviation compared to that of the damping factor of 0.40 .

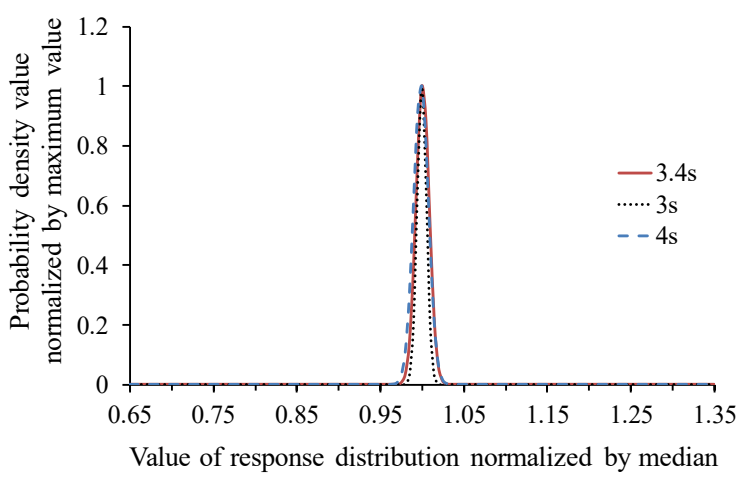

(a) $\mathrm{h}=0.05$

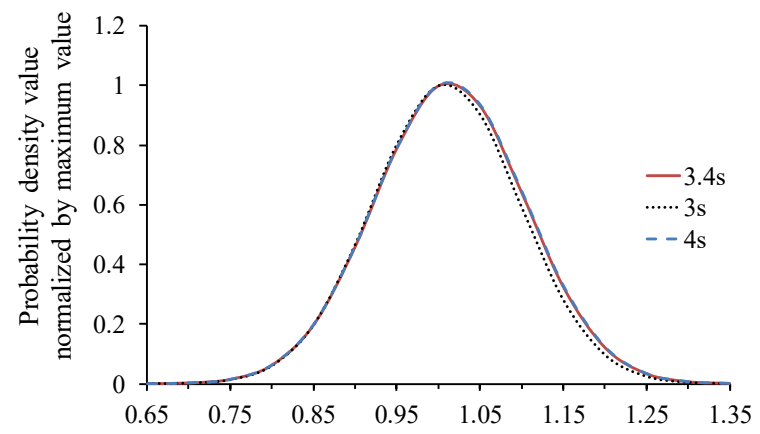

Value of response distribution normalized by median (b) $\mathrm{h}=0.40$

Fig. 5 Comparison of probability density functions with damping factors of 0.05 and 0.4 concerning horizontal natural period of $3 \mathrm{~s}$ to $4 \mathrm{~s}$. Varying the natural periods have little influence on the variance of the pseudo velocity. 
Fukasawa, Miyagawa, Uchita, Yamamoto, Miyazaki, Okamura and Fujita, Transactions of the JSME (in Japanese), Vol.87, No.898 (2021)

\section{4. 免震装置諸元のばらつき評価}

免震装置諸元のばらつきとして，厚肉積層ゴムとオイルダンパで想定される設計值との誤差率を設定する．ま た，この誤差率を免震装置として導入される基数として組み合わせた場合の影響をモンテカルロ法で評価する.

\section{$4 \cdot 1$ 免震装置諸元のばらつき}

厚肉積層ゴムについては，高速炉向けの厚肉積層ゴムを対象に設計值に対する水平・上下方向の剛性のばらつ きが検討されており(Fukasawa et al., 2018)，これに基づくと 99.7\%の信頼区間は以下となる．なお，それらの剛性 のばらつきは正規分布に対応することが確認されている.

・水平方向 : 99.7\%信頼区間 : $-7.4 \%$ から $+8.8 \%$

・上下方向 : 99.7\%信頼区間 : $-6.3 \%$ から $+6.6 \%$

高速炉向けのオイルダンパについては，減衰係数等のばらつきに関する試験データはない，そのため，以下の 仮定を導入して, オイルダンパの減衰係数のばらつきの区間を設定した.プラントに導入されるオイルダンパは, 加振試験により全数検査することを前提としている．その検査の合否基準は基準地震動で想定される荷重下で減 衰力や減衰係数が設計值に対して $\pm 10 \%$ 以下と想定している，そのため， $\pm 10 \%$ を超過するオイルダンパが含ま れないこととなる．また，本論文で対象としているオイルダンパは動粘度が比較的低いオイル（動粘度 $20^{\circ} \mathrm{C}:$ 約 $20.6 \mathrm{~mm}^{2} / \mathrm{s}$ ）の利用を想定している，これによって，雾囲気温度が減衰力の変動に及ぼす影響は小さいことが期 待される.よって，ここではその減衰力の変動は考慮しないものとした．以上を踏まえて，ここでは製作時に想 定されるばらつきとして，99.7\%の信頼区間を以下と仮定した。

•99.7\%信頼区間：-10.0\%から+10.0\%

\section{$4 \cdot 2$ 免震装置諸元と基数の関係}

厚肉積層ゴムとオイルダンパで想定される諸元のばらつきを踏まえて，これらを組み合わせた際の剛性や減衰 係数の変動をモンテカルロ法にて検証する.

厚肉積層ゴムの剛性とオイルダンパの減衰係数に関するばらつきを正規分布の確率密度関数を用いて表現する。 確率密度関数は上記の信頼区間を包含するように設定した，すなわち，平均值を $1.0 （ 1.0$ の場合，設計值に等し いことを意味する）として，99.7\%信頼区間で平均值に対して 0.9 から $1.1 （ 30 ： \pm 10 \% ）$ となるように標準偏差 を設定する．厚肉積層ゴムについては 99.7\%信頼区間の上限で $9 \%$ 程度となるが，ここでは土 $10 \%$ とした．これに より，厚肉積層ゴムの剛性については若干の保守性（ばらつきが大きくなることを意味する）を有することとな る.

装置一基あたりのばらつきは，上記で設定した確率密度関数を累積確率に変換して，ここに 0 から 1.0 の一様 乱数を与えて模擬する. さらに，これらを組み合わせた際の諸元の変動を確認するため，装置の基数を変数とし て，装置 1 基から 500 基まで増大させた場合の平均值を求める。このプロセスを解析の 1 ケースとして，これを 1000 ケース実施し，これらの結果を $99.7 \%$ 信頼区間の上下限值で評価する．なお，装置一基あたりのばらつきの 区間がその評価に及ぼす影響を確認するため，95\%信頼区間で設計值に対して $\pm 10 \% （ 20 ： \pm 10 \%)$ となる場合 についても評価した.

これによって得られた結果を図 6, 図 7 に示す。これらの図はばらつきを有する装置を組み合わせた際の平均 值（装置全体）と装置の基数の関係となっており，図6には 10 ケース分の解析結果を，図 7 には 1000 ケース分 の解析結果から 99.7\%信頼区間の上下限值で整理した結果を示している. 免震装置のばらつきを模擬するため, 二種類の確率密度関数を用いたが, これらは装置の基数 $n_{d}$ が増大寸るにつれて, 平均值が $\sqrt{n_{d}}$ に反比例しなが ら 1.0 (設計值) に収束する傾向が認められる. 装置の基数が 10 基を上回ると， $3 \sigma$ と $2 \sigma$ で士 $10 \%$ を仮定してい たばらつきは $5 \%$ 程度まで低減し，100 基では $1 \%$ 程度， 500 基では $0.4 \%$ ま゙低下寸る．さらに，30 と $2 \sigma$ の結果 を比較すると, 装置の基数が増加寸るにつれて両者の差は小さくなり, たとえば 100 基でその差は $0.5 \%$ 程度とな る.したがって，この差が地震応答に及ぼす影響は軽微であるといえる.

以上の結果から, 免震装置の基数が増大寸るにつれて設計值に対するばらつきは減少し, 数百基の免震装置の 導入を想定すると, 免震システムの諸元は設計值（平均值）と近い值となることが確認された. 
Fukasawa, Miyagawa, Uchita, Yamamoto, Miyazaki, Okamura and Fujita,

Transactions of the JSME (in Japanese), Vol.87, No.898 (2021)

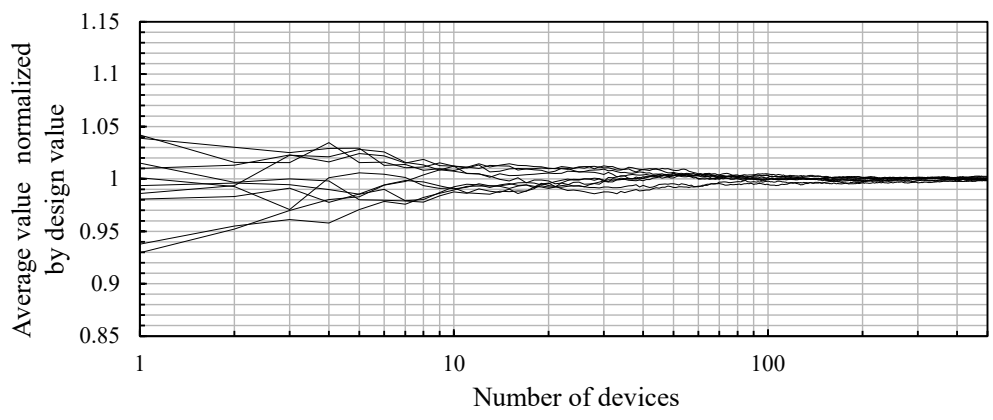

(a) $3 \sigma: \pm 10 \%$

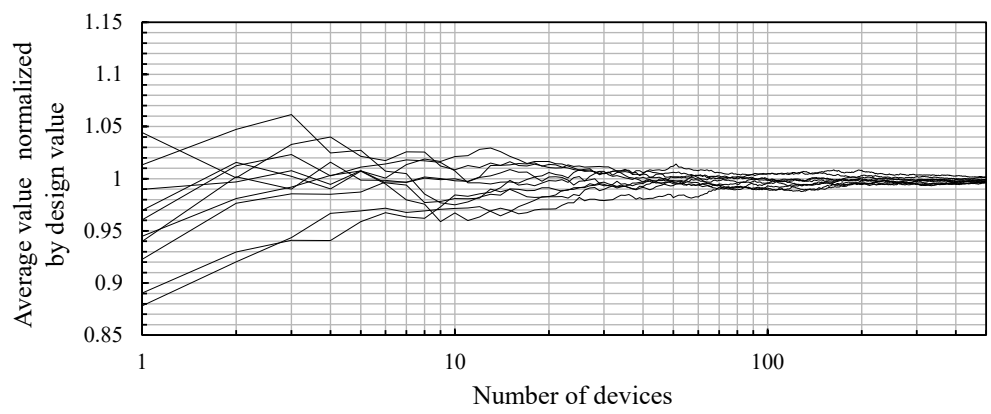

(b) $2 \sigma: \pm 10 \%$

Fig. 6 Relationships between number of isolation devices and design value, which are calculated by Monte Carlo approach. These relationships show that the trends of the average values normalized by the design value converge to 1.0 as the number of isolation devices increase.

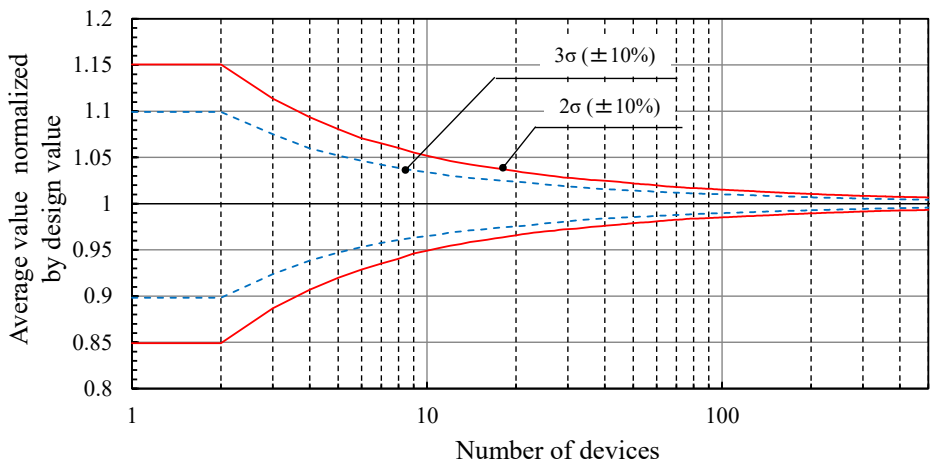

Fig. 7 Results of relationships between number of isolation devices and design value at $99.7 \%$ confidence intervals obtained from 1000 Monte Carlo simulations. The average values normalized by the design value converges to 1.0 as the number of isolation devices increase.

\section{5. 地震応答解析}

\section{$5 \cdot 1$ 解析方法}

模擬地震動が有する個々の特性と免震装置の諸元のばらつきを重畳させた解析条件で水平・上下同時入力によ る地震応答解析を実施する．利用する模擬地震動は第 3 章で作成した「高速炉向けの基準地震動」と JEAG4601 で規定される「震源を特定せず策定する地震動」の各々 100 波とした.

免震装置の諸元は「設計值」と「4. 免震装置諸元のばらつき評価」の結果を考慮した．後者については，地震 動レベルが相対的に大きい高速炉向けの基準地震動を対象に解析を行なった．ただし，解析で考慮する組み合わ せ数が膨大となるため,「4. 免震装置諸元のばらつき評価」の結果を基に 2 点推定法を用いて，免震装置の諸元 を設定した.

以上の条件で，模擬地震動と免震装置諸元のばらつきを重畳させて数百ケースの地震応答解析を行い，それら の結果から厚肉積層ゴムのせん断ひずみと軸応力を $95 \%$ と $99.7 \%$ 信頼区間で評価した. 
Fukasawa, Miyagawa, Uchita, Yamamoto, Miyazaki, Okamura and Fujita,

Transactions of the JSME (in Japanese), Vol.87, No.898 (2021)

\section{$5 \cdot 2$ 解析条件}

(1) 免震装置の諸元 : ばらつきを与える諸元として, ここでは厚肉積層ゴムの水平方向と上下方向の剛性およ びオイルダンパの減衰係数を対象とした. この 3 因子の変動を 2 点推定法により, 各諸元を設定した. その際, 各因子の設計值に対する変動は第 4 章での解析結果を基に $1 \%$ とする. この值は免震装置の基数を 100 基と仮定 したものであり, 導入基数が 100 基以上の場合には, さらにこの值よりも小さくなる.「高速炉の基準地震動」と 「震源を特定せず策定する地震動」の解析ケース数は各々 900 ケース ( 2 点推定法による 8 つの諸元と地震波の数 を掛け合わせた 800 ケースと設計諸元の 100 ケースを合わせた 900 ケース）と 100 ケース（設計諸元）となって いる.

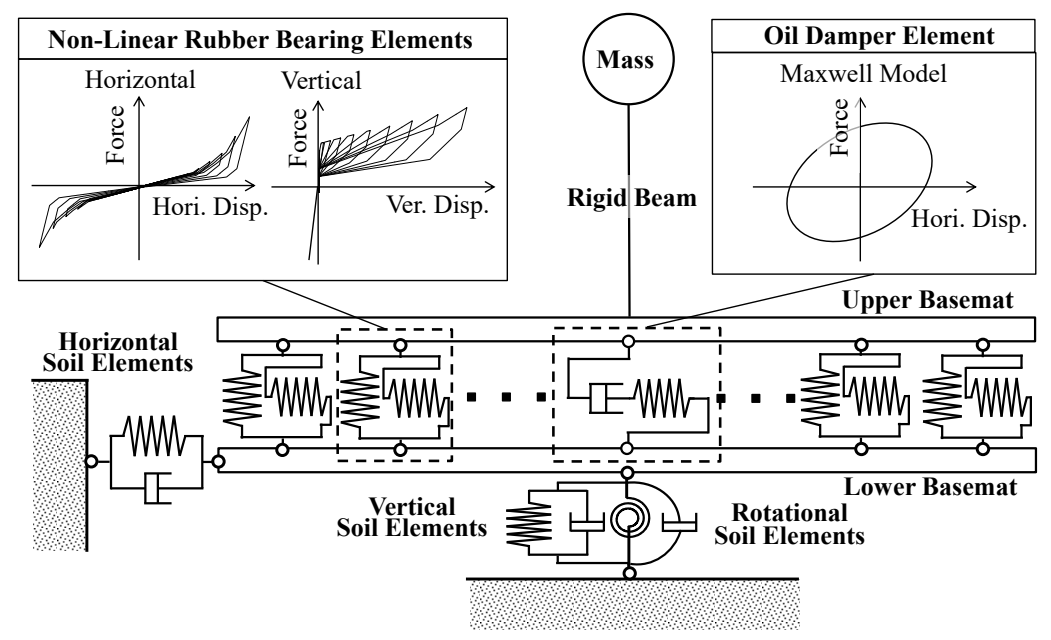

Fig. 8 Analytical model used by seismic response analysis. This analytical model enables the seismic response analysis to perform considering the input condition of the horizontal and vertical basis ground motions simultaneously (Fukasawa et al., 2018). The analytical model has the two degree of freedom system allowed for the reactor building mass and the base mat mass. It consists of the non-linear rubber bearing elements and the oil damper element to capture the force and displacement relationships of this isolation system.

（2）地震応答解析モデル : 地震応答解析には図 8 の地震応答解析モデルを用いる(深沢他，2018). この解析モデ ルは，建屋とベースマットの質量を考慮した 2 質点系で，水平・上下方向の同時入力による連成解析が可能とな っている. このモデルは水平・上下の相互作用をそれらの荷重一変位関係に反映するために, 水平方向の履歴モ デルについては上下応答で得られる軸力が，上下方向の履歴モデルについては水平応答で得られたせん断ひずみ が各々の履歴モデルに反映される. これによって, 両方向成分の岡性や履歴減衰が入力レベルに応じて逐次变化 しながら, 終局近傍の大きな変位に対して積層ゴムの履歴形状を再現することができる. このモデルには, 水平・ 上下方向の各々の履歴モデル（荷重一変位関係を構成するモデル）を 1 要素として, 水平・上下方向にそれぞれ 10 要素与えている. オイルダンパについては, これによって得られる減衰力を 1 要素の Maxwell モデルでモデル 化している.

\section{$5 \cdot 3$ 地震応答解析結果}

高速炉の基準地震動と震源を特定せず策定する地震動を入力して得られた地震応答解析結果を軸応力一せん断 ひずみ関係として整理した。この軸応力一せん断ひずみ関係には厚肉積層ゴムの線形限界曲面を併記した。これ は，1/2 縮尺サイズの厚肉積層ゴムを対象に破断試験（図 9）によって得られた図 10 の線形限界曲面と破断曲面 と対応したものとなっている(深沢他, 2017a) (Fukasawa et al., 2018).

（1）高速炉の基準地震動：高速炉の基準地震動を入力して得られた計 900 ケースの解析結果を軸応力一せん断 ひずみ関係として図 11(a)に示す．軸応力（引張側及び圧縮側）とせん断ひずみは時刻歴応答解析（水平・上下同 時入力）で得られた各々の最大応答值となっている．解析結果の軸応力とせん断ひずみは，諸元が設計值の場合 
Fukasawa, Miyagawa, Uchita, Yamamoto, Miyazaki, Okamura and Fujita,

Transactions of the JSME (in Japanese), Vol.87, No.898 (2021)

とこれから変動させた場合で有意な差は認められない，応答のばらつきを $95 \%$ と 99.7\%信頼区間で評価した結果 が表 1 である．なお，軸応力は設計面圧（5.0 MPa）を基点として，引張側と圧縮側に分類している.

上記の信頼区間の上限值を基にせん断ひずみと軸応力を各々中央值で正規化したものを図 12 に示す.せん断ひ ずみの $95 \%$ と $99.7 \%$ の信頼区間では各々約 1.2 と約 1.3 となった.

次に軸応力の結果について説明する. 軸応力は設計面圧を基準に圧縮側と引張側に分類される．圧縮側につい ては，95\%と 99.7\%の信頼区間で各々約 1.08 と約 1.1 となった. 引張側については，引張側で作用する応力は自 重作用時と非作用時（建屋の自重がキャンセルされて，積層ゴムに引張応力が作用する状態）に分類される．こ こでは裕度評価に係る自重非作用時についてみていく。この 95\%と 99.7\%信頼区間は中央值に対して，約 2.5 と 約 3.3 となる. 引張側の軸応力はせん断ひずみや圧縮側の軸応力に比べて, ばらつきが大きいことが確認された.

（2）震源を特定せず策定する地震動：震源を特定せず策定する地震動を入力した際の地震応答解析結果を軸応力 一せん断ひずみ関係で整理したものが図 11(b)である. なお, 本解析におけるオイルダンパの減衰力は応答変位が $0.35 \mathrm{~m}$ 以下となることから, 高速炉の基準地震動で設定した減衰係数を基準に 0.5 倍とした. これは等価減数定 数にして 0.2 に相当する. また, 本解析での諸元は設計值として計 100 波の模擬地震動を対象に解析を行った. これは前述の解析結果から，諸元を変動させた場合とこれを設計值とした場合で有意な差が生じなかったことに よる.

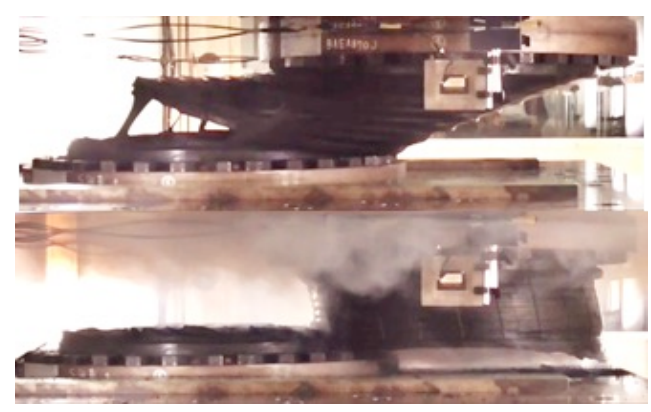

(a) Horizontal hardening test

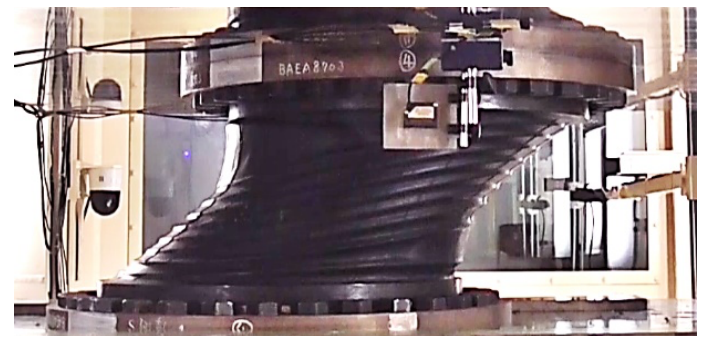

(b) Vertical softening test

Fig. 9 Breaking tests for thick rubber bearings. The horizontal hardening test and the vertical softening test were conducted using the half-scale model with $800 \mathrm{~mm}$ in diameter to investigate the ultimate performance, such as the breaking shear strain and the bearing tensile stress, for the thick rubber bearing (Fukasawa et al., 2018).

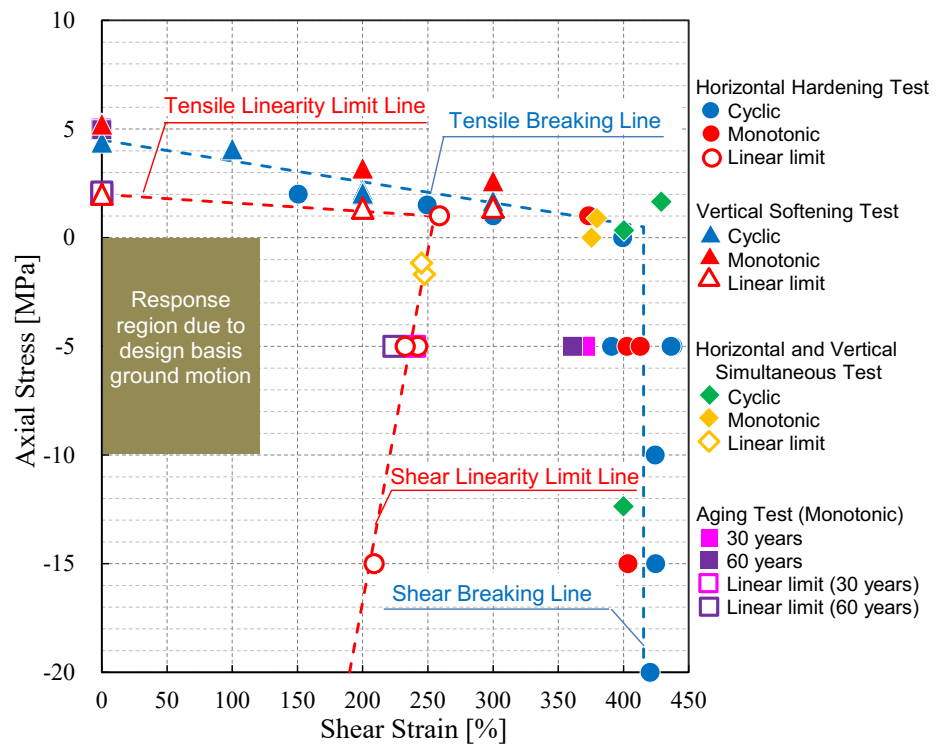

Fig. 10 Relationship between breaking shear strain and axial stress including linearity limit for thick rubber bearings obtained from horizontal hardening test and vertical softening test (Fukasawa et al., 2018). 
Fukasawa, Miyagawa, Uchita, Yamamoto, Miyazaki, Okamura and Fujita,

Transactions of the JSME (in Japanese), Vol.87, No.898 (2021)

震源を特定せず策定する地震動を入力とした場合のせん断ひずみおよび軸応力は，高速炉の基準地震動を入力 した場合と比べて小さくなる．軸応力の引張側については，自重が完全にキャンセルされることはなく，自重作 用下での応答となった．それらの応答を中央值で正規化したものを図 13 に示す．せん断ひずみについては $95 \%$ と $99.7 \%$ の信頼区間で各々約 1.2 と約 1.4 となった.

次に，軸応力についてみていく．軸応力（圧縮側）の 95\%と 99.7\%の信頼区間における中央值との比率は各々 1.04 と 1.07 となった. 軸応力の引張成分の応答が圧縮成分の応答と比べて相対的に大きくなるものの，両者のば らつきは高速炉の基準地震動で生じる応答と比べて小さい.

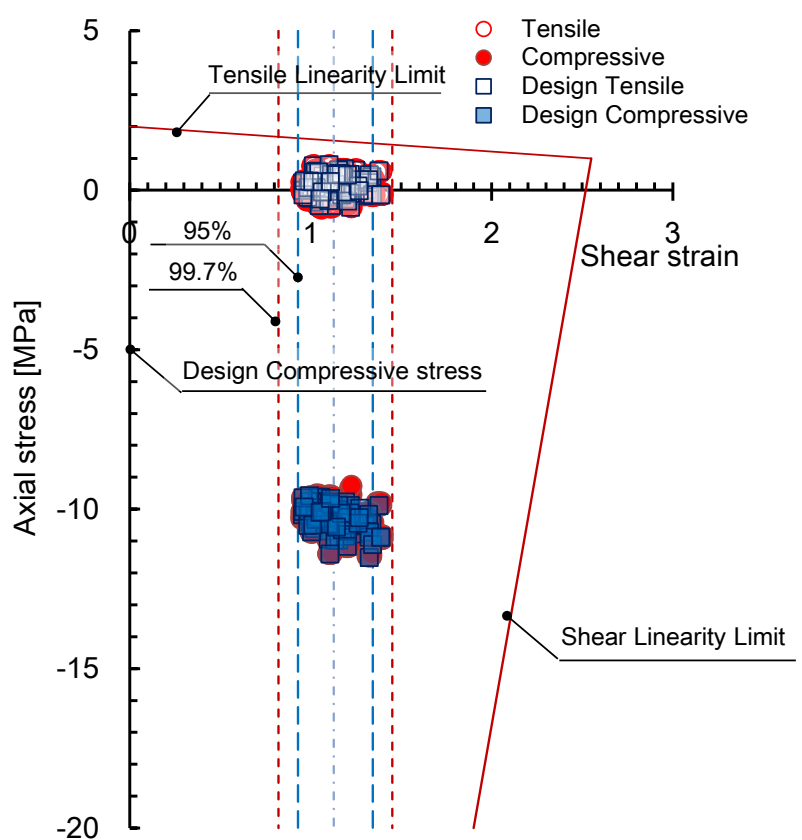

(a) Design basis ground motion of SFR

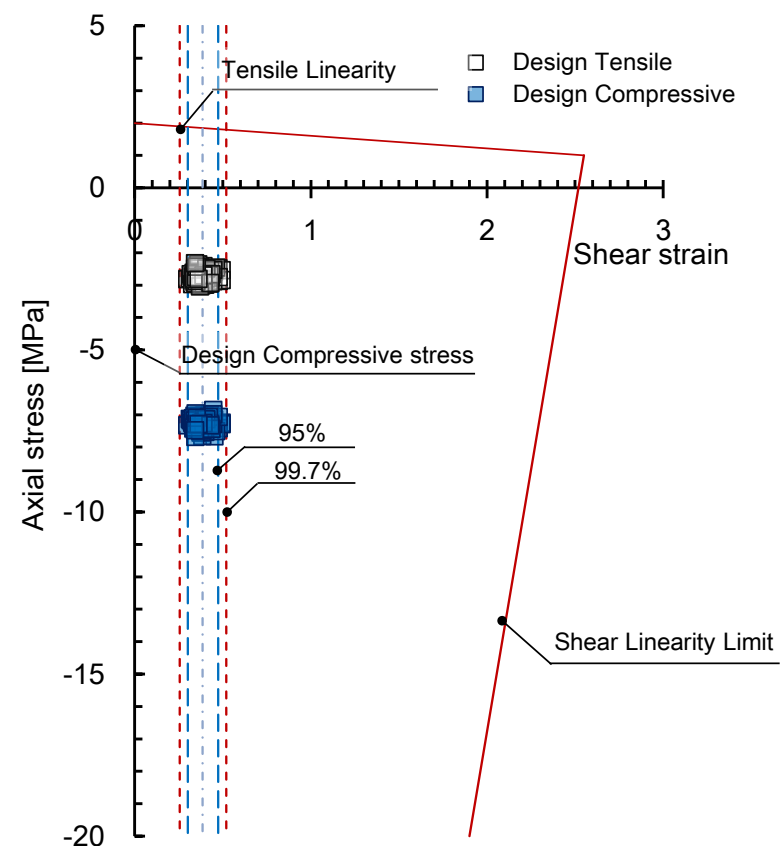

(b) Ground motion with non-specified source

Fig. 11 Analytical results of relationship between axial stress and shear strain obtained by maximum values. The axial stress ranges from the compressive region to the tensile region against the design basis ground motion of SFR. In contrast, the axial stress caused by the ground motion with non-specified source results in the compressive region.

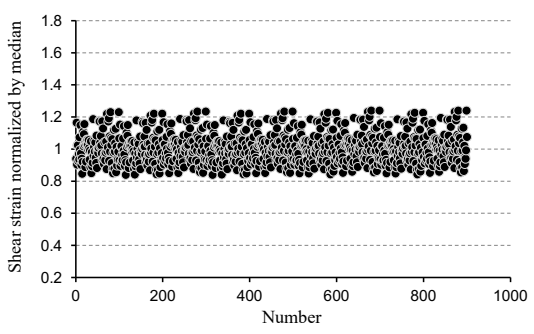

(a) Shear strain

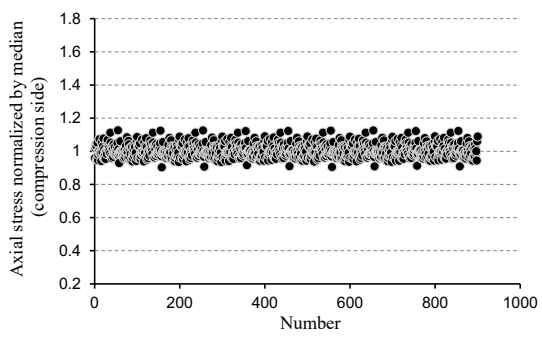

(b) Compressive stress

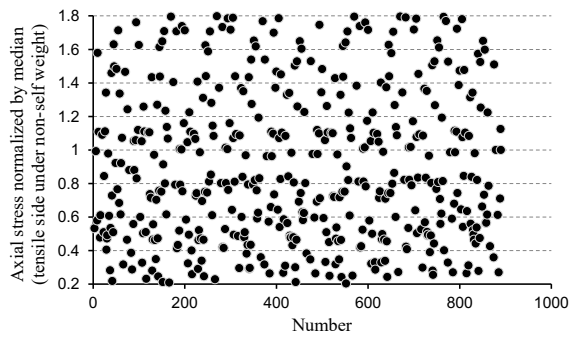

(c) Tensile stress

Fig. 12 Analytical results for design basis ground motion of SFR normalized by median. The variation in the tensile stress varies widely compared to the shear stress and the compressive stress. 


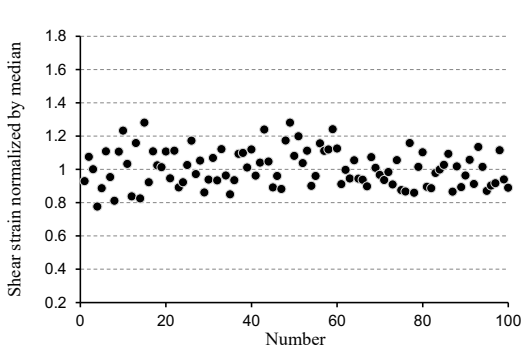

(b) Shear strain

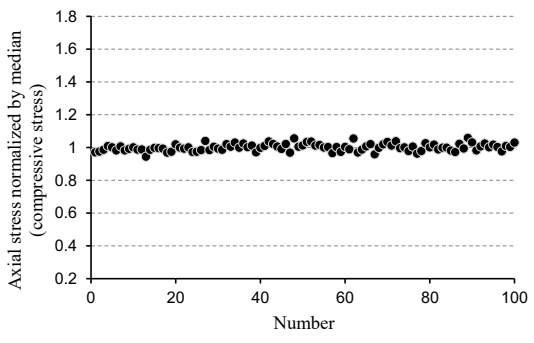

(b) Compressive stress

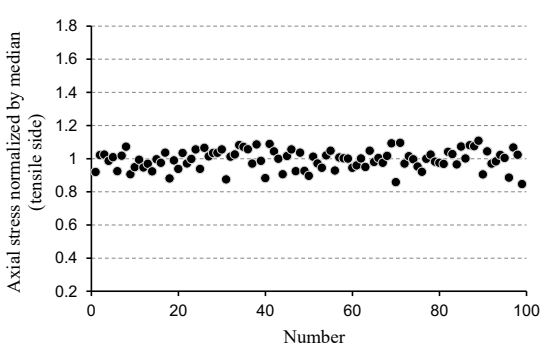

(c) Tensile stress

Fig. 13 Analytical results for ground motion with non-specified source normalized by median. Since the axial stress caused by the ground motion with non-specified source results in the compressive region, the variation in the tensile stress is small.

Table 1 Analytical results.

\begin{tabular}{ccccccc}
\hline & \multicolumn{3}{c}{$95 \%$ confidence interval } & \multicolumn{3}{c}{$99.7 \%$ confidence interval } \\
\cline { 2 - 7 } & Shear strain & Compressive stress & Tensile stress & Shear strain & Compressive stress & Tensile stress \\
\hline SFR & 1.34 & $11.06 \mathrm{MPa}$ & $0.69 \mathrm{MPa}$ & 1.45 & $11.47 \mathrm{MPa}$ & $0.89 \mathrm{MPa}$ \\
\hline $\begin{array}{c}\text { Ground motion with } \\
\text { non-specified source }\end{array}$ & 0.475 & $7.59 \mathrm{MPa}$ & - & 0.521 & $7.76 \mathrm{MPa}$ & - \\
\hline
\end{tabular}

\section{6. 安全余裕に関する考察}

\section{$6 \cdot 1$ 線形限界曲面を用いた評価}

ここでは線形限界曲面を用いて，設計上の許容限界に対する安全余裕を評価する，評価にあたっては，前章の 地震応答解析で得られた「せん断ひずみ」および「引張応力」の 99.7\%信頼区間の上限值を用いる。この評価で は, 安全余裕を安全余裕（裕度） = 許容限界 / 99.7\%信頼区間（上限值）の地震応答として求める. また，線形 限界曲面で与えられる許容限界は, せん断ひずみについては圧縮応力により, 引張応力についてはせん断ひずみ により変化する. したがって，ここではそれらの 99.7\%信頼区間の上限值と中央值で評価する.

なお，本評価では経年変化のデータが十分に得られていないため，その影響を考慮していないが，著者らが行 った経年促進劣化の試験では, 経年により設計時の岡性に比べて大きくなることが確認されている(渡壁他, 2017). 一般に地震応答解析では剛性が大きくなると，地震動に対する応答変位（ひずみ）は生じにくくなる．これによ って，線形限界曲面（許容限界）に対する安全余裕を大きく見積もる恐れがある，そのため，ここでは経年によ る影響は考慮していない。

表 2 に高速炉の基準地震動と震源を特定せず策定する地震動に対して, JEAG4614 に基づき裕度を評価した結 果をまとめた．せん断ひずみや軸応力の最大值の重妏合わせを想定した場合でもJEAG4614 の要求値に対して, およそ 1.5 倍以上の裕度をもって満足することが確認された。 したがって, 許容限界は地震応答（軸応力やせん 断ひずみ）によって変動するものの, 設計面圧下（5.0 MPa）で許容限界に対して2 倍の安全余裕を確保して設計

（減衰力の調整）を行えば，地震応答のばらつきの要因となる模擬地震動や免震諸元を重畳させた地震応答に対 して，一定の信頼度をもって評価を満足することが確認された。

加えて, 高速炉の基準地震動を基準に, これを係数倍して許容限界の超過確率を次式により $95 \%$ と $50 \%$ 信頼度 で評価したものが図 14 となる.

$$
P_{f}=\Phi\left(\frac{\ln (A)-\ln \left(A_{m}(A)\right)+\beta_{U} \Phi^{-1}(Q)}{\beta_{R}}\right)
$$

ここに， $P_{f}$ は線形限界を超過する確率， $A$ は現実的な地震応答， $A_{m}$ は耐力の中央值， $\beta_{U}$ は認識論的不確実さ, $\beta_{R}$ は偶然的不確実さ， $Q$ は認識論的不確実さを考慮した非超過確率， $\Phi()$ は標準正規分布であり， $\Phi^{-1}()$ は $\Phi$ 逆関 
Fukasawa, Miyagawa, Uchita, Yamamoto, Miyazaki, Okamura and Fujita,

Transactions of the JSME (in Japanese), Vol.87, No.898 (2021)

数である.ここでは, 認識論的不確実さの対数標準偏差 $\beta_{U}$ にいては 0.1 とし, せん断ひずみと引張応力の偶然 的不確実さの対数標準偏差 $\beta_{R}$ については解析結果を基に各々 0.13 と 0.08 とした. なお， $\beta_{R}$ につては $2.5 \mathrm{Ss}$ ま での地震応答解析結果を踏まえて設定した. その結果, 基準地震動（1.0 Ss）ではせん断ひずみおよび引張応々と もに許容限界を超過する有意な確率は生起していない，せん断ひずみについては基準地震動における線形限界の 超過確率は極めて 0 に近い. 95\%信頼度の許容限界の超過確率については, 基準地震動の 1.3 倍から 1.5 倍の入力 レベルで線形限界の超過確率が生起する，そして，およそ基準地震動の 2 倍の入力レベルで許容限界の超過確率 が 1.0 に至る. 引張側についても基準地震動の 1.2 倍から 1.3 倍の入力レベルで許容限界の超過確率が生起する. その後，およそ 1.5 倍から 1.8 倍の入力レベルで許容限界の超過確率が 1.0 に至る.

以上の結果から, 本免震システムは高速炉の基準地震動に対して設計で要求される安全余裕が確保され，かつ 許容限界を超過する確率が極めて小さいことが確認された.

Table 2 Evaluation results of safety margin based on JEAG 4614.

\begin{tabular}{ccccc}
\hline & \multicolumn{2}{c}{$99.7 \%$ confidence interval } & \multicolumn{2}{c}{ Median } \\
\cline { 2 - 5 } & Shear strain & Tensile stress & Shear strain & Tensile stress \\
\hline SFR & 1.49 & 1.60 & 1.52 & 1.74 \\
\hline $\begin{array}{c}\text { Ground motion with } \\
\text { non-specified source }\end{array}$ & 4.38 & - & 4.41 & - \\
\hline
\end{tabular}

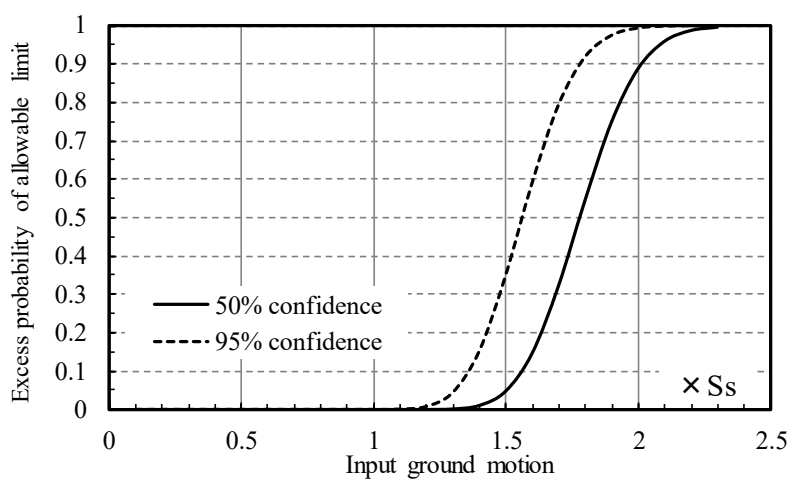

(a) Horizontal direction

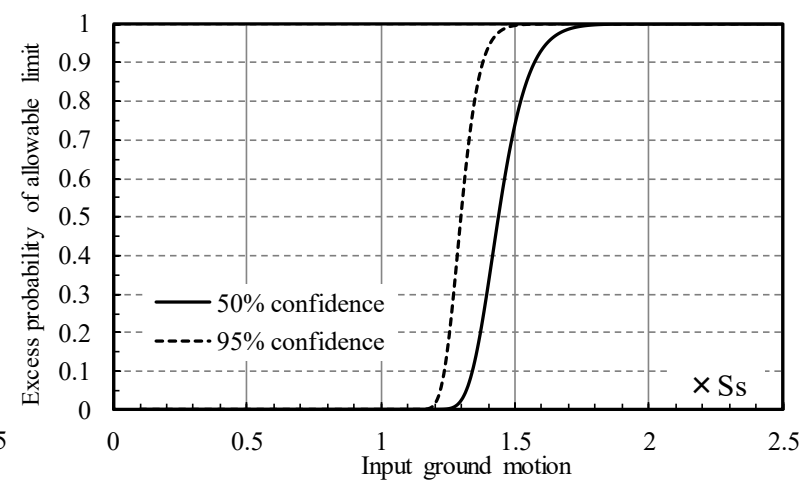

(b) Tensile direction

Fig. 14 Relationships between excess probability of allowable limit and input ground motions of SFR. The excess probability of allowable limit results in extremely small against $1.0 \mathrm{Ss}$. The excess probability of allowable limit at $95 \%$ confidence reaches 1.0 against $2.0 \mathrm{Ss}$ for the horizontal direction. For the tensile direction, it reaches 1.0 against 1.5 Ss.

\section{$6 \cdot 2$ 確率論に基づく評価}

ここでは，基準地震動に対する免震装置の線形限界の超過確率と安全余裕の観点から考察する．免震装置の線 形限界を $R$, 荷重を $S$ として, 各々が独立の正規分布をなすものとする.このとき, $R>S$ の関係が成立する場合 には免震装置の安全余裕が確保される。一方，この関係が $R<S$ となった場合には荷重が線形限界を超過すると 定義する. この時, 積層ゴムの水平方向および上下方向の復元力は各々ハードニング特性およびソフトニング特 性となる. $R$ と $S$ の差を $Z=R-S$ とすると, $Z$ も正規分布（平均值： $Z o$, 標準偏差 : $\sigma Z$ ） となることから, 線形 限界を超過する確率 $P_{f}$ は次式で与えられる.

$$
\begin{aligned}
P_{f} & =\frac{1}{\sqrt{2 \pi} \sigma_{Z}} \int_{-\infty}^{0} \exp \left\{-\frac{1}{2}\left(\frac{Z-Z_{o}}{\sigma_{Z}}\right)^{2}\right\} d z \\
& =1-\Phi\left(\frac{Z_{o}}{\sigma_{Z}}\right)
\end{aligned}
$$


Fukasawa, Miyagawa, Uchita, Yamamoto, Miyazaki, Okamura and Fujita,

Transactions of the JSME (in Japanese), Vol.87, No.898 (2021)

平均值 $Z_{o}$ が線形限界超過点 $(Z=0)$ から $\sigma_{Z}$ の隔たりを安全性指標 $\beta$ で表現すると次式の関係が成り立つ.

$$
\beta=\frac{Z_{o}}{\sigma_{Z}}=\frac{R_{o}-S_{o}}{\sqrt{\sigma_{r}^{2}+\sigma_{s}^{2}}}
$$

ここで，分布の平均值および標準偏差を各々 $R_{o} ， S_{o}$ および $\sigma_{r} ， \sigma_{s}$ とする. 上式を線形限界と荷重の平均值の比 $f_{c}\left(R_{o} / S_{o}\right)$ と各々の変動係数 $V_{r}, V_{s}$ を用いて整理すると線形限界を超過する確率は次式となる. なお， $f_{c}$ は線形 限界と荷重(応答)の比となるため, 安全率（中央安全率）と解釈できる.

$$
P_{f}=1-\Phi\left(\frac{f_{c}-1}{\sqrt{f_{c}^{2} V_{r}^{2}+V_{s}^{2}}}\right)
$$

さらに，荷重も而力も対数正規分布に従う場合を考える. 正規分布による超過確率から，対数正規分布に従う 超過確率 $P_{f}$ は次式で与えられる.

$$
\begin{aligned}
& P_{f}=1-\Phi\left(\frac{R_{L o}-S_{L o}}{\sqrt{{\sigma_{L r}}^{2}+{\sigma_{L s}}^{2}}}\right) \\
& R_{L o}=\ln \frac{R_{o}}{\sqrt{1+V_{r}^{2}}} \\
& S_{L o}=\ln \frac{S_{o}}{\sqrt{1+V_{s}^{2}}} \\
& {\sigma_{L r}}^{2}=\ln \left(1+V_{r}^{2}\right) \\
& {\sigma_{L s}}^{2}=\ln \left(1+V_{s}^{2}\right)
\end{aligned}
$$

上式を許容限界と荷重の平均值の比 $f_{c}$ を用いて整理すると次式が得られる.

$$
P_{f}=1-\Phi\left(\frac{\ln \left(f_{c} \sqrt{\frac{1+V_{s}^{2}}{1+V_{r}^{2}}}\right)}{\sqrt{\ln \left[\left(1+V_{r}^{2}\right)\left(1+V_{s}^{2}\right)\right]}}\right)
$$

正規分布と対数正規分布とで分布の違いが許容限界の超過確率と安全率の関係に及ぼす影響を確認するため, それらの分布の変動係数を 0.05 から 0.15 まで変化させたものが図 15 である. 許容限界の超過確率と安全率の関 係は変動係数が小さくなるにつれて, 許容限界の超過確率を満足させる安全率も小さくなる. 一方, 変動係数が 大きくなると，許容限界の超過確率を満足させるために必要となる安全率は大きくなる. 
Fukasawa, Miyagawa, Uchita, Yamamoto, Miyazaki, Okamura and Fujita,

Transactions of the JSME (in Japanese), Vol.87, No.898 (2021)

正規分布と対数正規分布を比較すると，変動係数が小さい場合には超過確率と安全率の関係のカーブは正規分 布と対数正規分布とでよく対応する. しかし, 変動係数の増加によって, 両者は異なった傾向を示す. 加えて, 対象とする超過確率が小さくなるにつれて両者の傾向は異なる. したがって, 変動係数が大きく, かつ対象とす る超過確率が小さい場合には分布の違いによって超過確率と安全率の関係に与える影響は大きくなるため，この ような場合には変動係数や分布を精緻なデータを基に設定する必要がある. 次に任意の超過確率を満足するため の安全率をみた場合, 対数正規分布と比べて正規分布の安全率が大きくなる．たとえば，10-5 以下の超過確率を 対象とした場合，正規分布は対数正規分布よりも安全側の安全率を与える.

そこで，正規分布に従う超過確率と安全率の関係式(式(4))を用いて，地震応答解析結果から，せん断ひずみと 引張応力に関する線形限界の超過確率と安全率の関係を求めたものが図 16 である.ここでは, せん断ひずみと引 張応力に関寸る線形限界の変動係数 $V_{r}$ を各々 0.024 と 0.019 とした. これは, それらの線形限界が水平・上下方向 の各々の剛性の変動に対応するものと仮定したことによる. 荷重に関する変動係数 $V_{s}$ は上述の地震応答解析を基 に表 3 のとおり設定した.

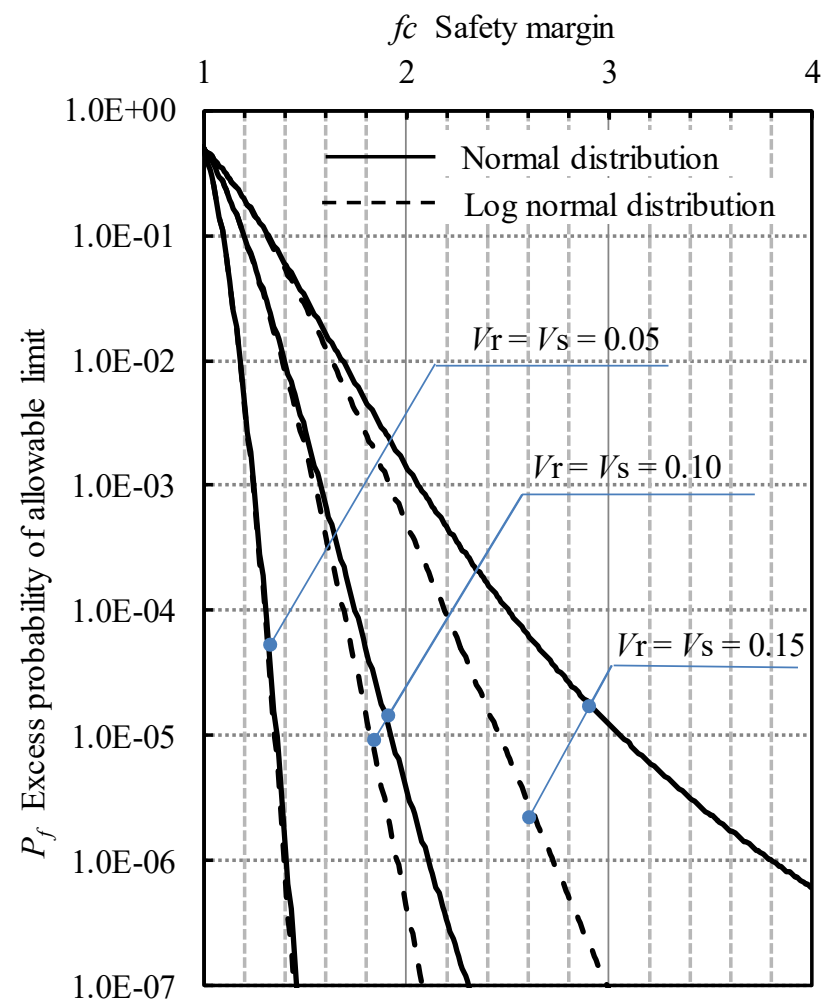

Fig. 15 Relationships between excess probability of allowable limit and safety margin. A large safety margin requires as the coefficient variations increase and the excess probability of allowable limit decreases. The normal distribution leads to a large safety margin compared to the log normal distribution.

Table 3 Coefficient of variation $V_{s}$.

\begin{tabular}{ccc}
\hline & Shear strain & Tensile stress \\
\hline SFR & 0.093 & 0.657 \\
\hline $\begin{array}{c}\text { Ground motion with } \\
\text { non-specified source }\end{array}$ & 0.111 & 0.059 \\
\hline
\end{tabular}


Fukasawa, Miyagawa, Uchita, Yamamoto, Miyazaki, Okamura and Fujita, Transactions of the JSME (in Japanese), Vol.87, No.898 (2021)

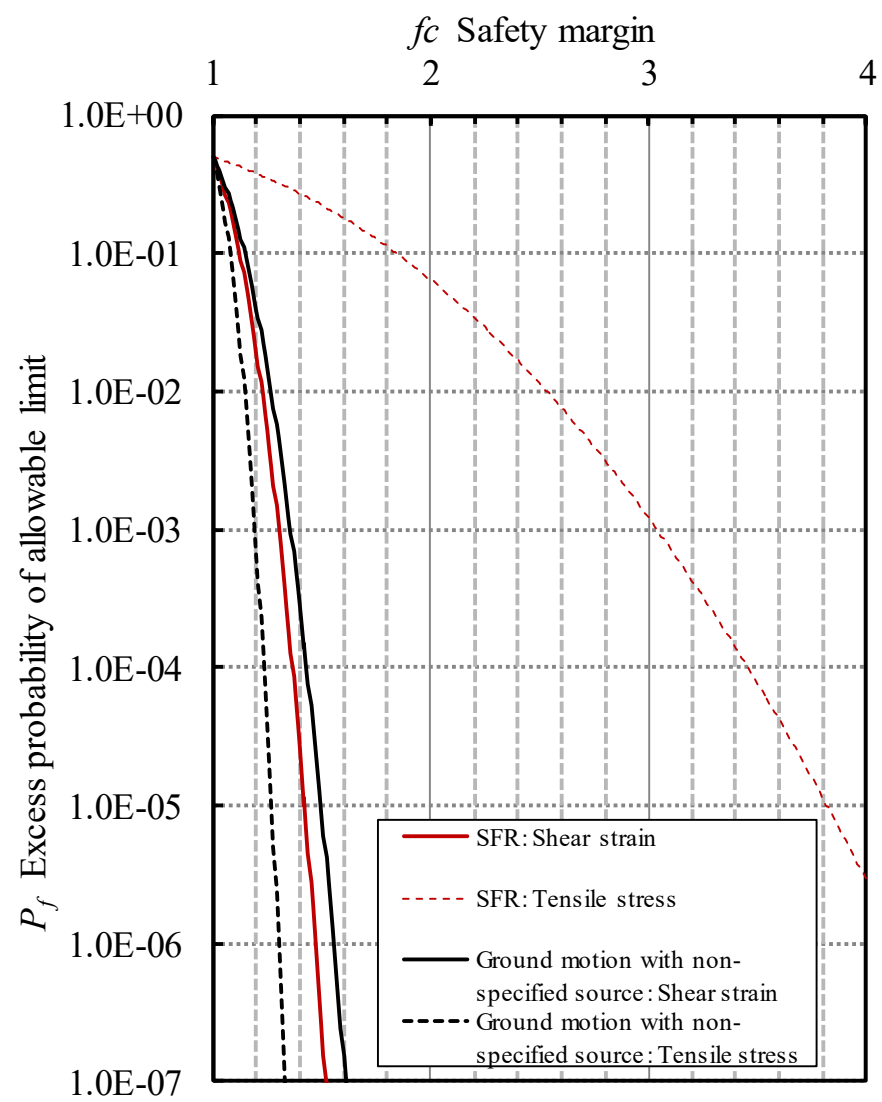

Fig. 16 Evaluation results of relationships between excess probability of allowable limit and safety margin. The tensile stress caused by the input ground motion of SFR requires a large safety margin in comparison with others because the variation coefficient of the tensile stress has the largest. The safety margin of tensile stress for SFR to satisfy the excess probability of allowable limit of $1.0 \times 10^{-5}$ results in 3.82 .

Table 4 Safety margin to satisfy $1.0 \times 10^{-5}$.

\begin{tabular}{ccc}
\hline & Shear strain & Tensile stress \\
\hline SFR & 1.42 & 3.82 \\
\hline JEAG4601-2015 & 1.50 & 1.27 \\
\hline
\end{tabular}

線形限界の超過確率と安全率の関係を評価した結果，せん断ひずみについては，オイルダンパによってせん断 ひずみが制御されるため, その変動係数は地震動の加速度レベルの違いによる影響を受けにくい. これによって, 高速炉と JEAG4601 の基準地震動に対する線形限界の超過確率と安全率の関係はおおむね同一のカーブを描き， 安全率に有意な差は生じていない. 一方, 引張応力については地震動の加速度レベルの増大とともに, その変動 係数が大きくなるため, 震源を特定せず策定する地震動と高速炉の基準地震動とでは線形限界の超過確率と安全 率の関係のカーブが異なっており，超過確率を満たすために必要な安全率にも差が生じている，ここで，参考ま でに任意の超過確率から，これに必要となる安全率を算出する.JEAC4601 では，基準地震動の発生確率が $10^{-4}$ から $10^{-5}$ として定義されている。 したがって，ここでは，超過確率として $1.0 \times 10^{-5}$ で必要となる安全率を評価す る.この超過確率を満足させるための安全率は表 4 となる. 高速炉の基準地震動での引張応力を除いて, 安全率 は 1.5 程度となる。

次に，上記の評価で最もクリティカルとなった引張応力（SFR）の安全率の成立性について検証する. 地震応 答解析で得られた引張応力の平均值は $0.301 \mathrm{MPa}$ である. また, せん断ひずみの平均值における引張方向の線形 限界の応力(許容限界)は $1.55 \mathrm{MPa}$ となる. それらの比率（許容限界/引張応力の平均值）を安全率とすると 5.17 となる.この比率は $1.0 \times 10^{-5}$ で要求される安全率の 3.82 よりも大きい. したがって，本免震システムは高速炉の 
Fukasawa, Miyagawa, Uchita, Yamamoto, Miyazaki, Okamura and Fujita, Transactions of the JSME (in Japanese), Vol.87, No.898 (2021)

基準地震動に対して線形限界の超過確率 $1.0 \times 10^{-5}$ を満足していることとなる. さらに，線形限界の超過確率を $1.0 \times 10^{-6}$ とした場合, これに必要な安全率は約 4.15 となるが, これについても満足している.

\section{7. まとめ}

本論文では免震構造の地震応答のばらつきを誘発する因子として模擬地震動の特性と免震装置の諸元に着目し， これらを重畳させた地震応答解析を通じて免震構造の安全余裕について考察したそその結果は以下のとおり要約 される。

・積層ゴムの線形限界曲面は地震応答によって変動するが, 設計面圧下で線形限界（せん断ひずみ）に対して 2 倍の安全余裕を確保寸れば, 地震応答のばらつきの要因となる模擬地震動や免震諸元の変動を重畳させた 地震応答に対して，一定の信頼度をもって JEAG4614 で要求される評価を満足することが確認された.

・基準地震動に対する線形限界の超過確率と安全率の関係を検証した結果, 基準地震動の加速度レベルが増大 するにつれて, せん断ひずみに比べて引張応力の変動係数が大きくなる. これによって, 線形限界の超過確 率を満たすために必要な安全率は大きくなる傾向が認められた.

・ 本免震システムでは高速炉の基準地震動に対して引張応力の安全率の確保が最もクリティカルとなったが, 線形限界の超過確率を $1.0 \times 10^{-6}$ とした場合でも，これに必要な安全率が確保される見通しが得られた.

確率論に基づく評価では，その確率の評価として $1.0 \times 10^{-5}$ 以下となることが想定される．このような確率下で は図 15 に示寸とおり, 荷重や耐力の変動係数の小さな違いで確率や安全率に大きな影響を及ぼすこととなる. 本 検討で用いた線形限界は限定的な試験体の基数で得られたものである. また，線形限界の変動係数については仮 定条件下で評価している。よって，今後は線形限界回りに着目した試験を行い，それらのデータの充足を図りな がら本論文で例示した評価方法の精緻化を行う計画である.

なお，本報告は経済産業省からの受託事業である「高速炉の国際協力等に関する技術開発」の一環として実施 した成果の一部である.

\section{文献}

深沢剛司，岡村茂樹，山本智彦，廣谷勉，森泉瑛里子，櫻井祐，森隆浩，正木信男，高速炉に適用寸る厚肉積層ゴム の 1/2 縮尺試験体を用いた終局特性評価，日本建築学会構造系論文集，Vol. 82, No. 740 (2017a), pp. 1641-1651.

Fukasawa, T., Okamura, S., Yamamoto, T., Kawasaki, N., Hirotani, T., Moriizumi, E., Sakurai, Y. and Masaki, N., Research and development of rubber bearings for sodium-cooled fast reactor-Ultimate properties of half-scale thick rubber bearings based on breaking tests, ASME Journal of Pressure Vessel Technol, PVT-16-1160 (2018), DOI: $10.1115 / 1.4038435$.

深沢剛司, 岡村茂樹, 山本智彦, 川崎信史, 稲葉学, 杣木孝裕, 鮫島祐介, 正木信男, 高速炉に適用する厚肉積層ゴ ムの研究開発（縮尺試験体を用いた載荷試験に基づく設計式の構築），日本機械学会論文集，Vol. 83，No. 852 (2017b), DOI: 10.1299/transjsme.17-00050.

深沢剛司, 岡村茂樹, 山本智彦, 川崎信史, 杣木孝裕, 櫻井祐, 正木信男, 高速炉に適用する厚肉積層ゴムの研究開 発（1/2 縮尺厚肉積層ゴムを用いた静的載荷試験に基づく履歴モデルの構築), 日本機械学会論文集，Vol. 84, No. 859 (2018), DOI:10.1299/transjsme.17-00502.

渡壁智祥, 山本智彦, 深沢剛司, 岡村茂樹, 杣木孝裕, 諸菱亮太, 櫻井祐, 加藤 亨二, 高速炉に適用する厚肉積層 ゴムの研究開発（準実大厚肉積層ゴムを用いた経年特性試験），日本機械学会論文集，Vol. 83, No. 850 (2017), DOI: 10.1299/transjsme.16-00444.

\section{References}

Fukasawa, T., Okamura, S., Yamamoto, T., Hirotani, T., Moriizumi, E., Sakurai, Y., Mori, T. and Masaki, N., Ultimate characterization of half scale model thick rubber bearings for SFR, Journal of Structural and Construction Engineering (Transactions of AIJ), Vol. 82, No. 740 (2017a), pp. 1641-1651 (in Japanese).

Fukasawa, T., Okamura, S., Yamamoto, T., Kawasaki, N., Hirotani, T., Moriizumi, E., Sakurai, Y. and Masaki, N., Research and development of rubber bearings for sodium-cooled fast reactor-Ultimate properties of half-scale thick rubber bearings based on breaking tests, ASME Journal of Pressure Vessel Technol, PVT-16-1160 (2018), DOI: 
Fukasawa, Miyagawa, Uchita, Yamamoto, Miyazaki, Okamura and Fujita,

Transactions of the JSME (in Japanese), Vol.87, No.898 (2021)

$10.1115 / 1.4038435$.

Fukasawa, T., Okamura, S., Yamamoto, T., Kawasaki, N., Inaba, S., Somaki, T., Samejima, Y. and Masaki, N., Research and development of thick rubber bearing for SFR - Design formulas for thick rubber bearing based on static loading test utilized scale model, Transactions of the JSME (in Japanese), Vol. 83 No. 852 (2017b), DOI: 10.1299/transjsme.17-00050.

Fukasawa, T., Okamura, S., Yamamoto, T., Kawasaki, N., Somaki, T., Sakurai, Y. and Masaki, N., Research and development of thick rubber bearing for SFR - Hysteresis model for thick rubber bearing based on static loading tests, Transactions of the JSME (in Japanese), Vol. 84 No. 859 (2018), DOI:10.1299/transjsme.17-00502.

Watakabe, T., Yamamoto, T., Fukasawa, T., Okamura, S., Somaki, T., Morobishi, R., Sakurai, Y., Kato, K., Research and development of thick rubber bearing for SFR-Aging properties tests of semi full-scale thick rubber bearing, Transactions of the JSME (in Japanese), Vol. 83, No. 850 (2017), DOI: 10.1299/transjsme.16-00444. 